\title{
Thermal modeling of three lakes within the continuous permafrost zone in Alaska using LAKE 2.0 model
}

Jason A. Clark ${ }^{1}$, Elchin E. Jafarov ${ }^{2,3}$, Ken D. Tape ${ }^{1}$, Benjamin M. Jones ${ }^{4}$, and Victor Stepanenko ${ }^{5,6}$

${ }^{1}$ Geophysical Institute, University of Alaska Fairbanks, AK, USA

$5 \quad{ }^{2}$ Earth and Environmental Sciences Division, Los Alamos National Laboratory, Los Alamos, NM, USA

${ }^{3}$ Woodwell Climate Research Center, Falmouth, MA, USA

${ }^{4}$ Institute of Northern Engineering, University of Alaska Fairbanks, AK, USA

${ }^{5}$ Lomonosov Moscow State University, Moscow, Russia

${ }^{6}$ Moscow Center for Fundamental and Applied Mathematics, Moscow, Russia

10 Correspondence to: Jason A. Clark (jaclark2@alaska.edu) 
Abstract. Lakes in the Arctic are important reservoirs of heat with much lower albedo in summer and larger absorption of solar radiation than surrounding tundra vegetation. In the winter, lakes that do not freeze to their bed have a mean annual bed temperature $>0{ }^{\circ} \mathrm{C}$ in an otherwise frozen landscape. Under climate warming scenarios, we expect Arctic lakes to accelerate thawing underlying permafrost due to warming waters in the summer and in the winter. Previous studies of Arctic lakes have focused on ice cover and thickness, the ice decay process, catchment hydrology, lake water balance, and eddy covariance measurements, but little work has been done in the Arctic to model lake heat balance. We applied the LAKE 2.0 model to simulate water temperatures in three Arctic lakes in Northern Alaska over several years and tested the sensitivity of the model to several perturbations of input meteorological variables (precipitation, shortwave radiation, and air temperature). The LAKE model is a one-dimensional model that explicitly solves vertical profiles of water state variables on a grid. We used a combination of meteorological data from local and remote weather stations, as well as data derived from remote sensing, to drive the model. We validated modelled water temperatures with data of observed lake temperatures at several depths. Our validation of the LAKE model completes a necessary step toward modelling changes in Arctic lake ice regimes, lake heat balance, and thermal interactions with permafrost. The sensitivity analysis shows us that the LAKE model is not highly sensitive to the weather data perturbations used in this study. Our results show that snow depth and lake ice strongly affect water temperatures during the frozen season which dominates the annual thermal regime. These findings suggest that reductions in lake ice thickness and duration could lead to more heat storage by lakes and enhanced permafrost degradation.

\section{Introduction}

Forty percent of Arctic lowlands are covered by lakes (Grosse et al., 2013). Lakes in the Arctic are important reservoirs of heat (Williamson et al., 2009) that affect permafrost thaw and carbon and methane emissions (Rowland et al., 2011; Abnizova et al., 2012). Lake water temperatures regulate heat fluxes, biogeochemical activity, and are influenced by meteorological conditions and the surface radiative balance (Abnizova et al., 2012; Jeffries et al., 1999; Arp et al., 2011; Wik et al., 2016; Rouse et al.,

35 1997). Increasing lake temperatures can thaw underlying permafrost, creating taliks and enhancing surface-groundwater interactions (Rowland et al., 2011; Jorgenson et al., 2006; Jorgenson and Shur, 2007). Understanding and modeling water temperatures in permafrost landscapes is critical to be able to predict future talik development, permafrost thaw, and greenhouse gas releases (Grosse et al., 2013).

Multiple lake models attempt to capture temperature variability in Arctic lakes. Zero-dimensional models are used primarily in

40 long timescale studies and have simplified numerical schemes allowing for computational efficiency (Mironov, 2008; Kirillin et al., 2011). The one-dimensional models have more sophisticated physical parametrization of the hydro- and thermo-dynamical processes and can effectively simulate fine scale temporal (hourly, daily) thermal and biogeochemical processes. Recent twodimensional models add advective heat transport through groundwater flow (Rowland et al., 2011; Grenier et al., 2018; Provost and Voss, 2019). Three-dimensional models couple three-dimensional surface flow to three-dimensional groundwater flow

45 (Spanoudaki et al., 2009; Rueda and MacIntyre, 2010; Painter et al., 2016; Painter, 2011). Most high-fidelity physics models require an increase in computing time. Using high temporal resolution meteorological data adds an additional burden to the compute time. Grant et al., (2021) stressed the important role of one-dimensional models serving as an optimal solution/tool when it comes to perform multiple runs for large numbers of lakes under different scenarios of climate change. 
We use the one-dimensional LAKE 2.0 model, which has been in active development since 2011, presenting a compromise

50 between explicit resolution of key physical processes and computational efficiency (Stepanenko et al., 2011, 2016; Iakunin et al., 2020). This one-dimensional model allows high temporal resolution input data and computational efficiency combined with effective reproducibility of the thermodynamics of lakes. An advantage of the LAKE model in context of climate-lakepermafrost interaction studies, is that it explicitly simulates phase transitions in underlying ground at different depth zones of bottom sediments (Stepanenko et al., 2016).

55 The original version of the LAKE model was developed by Stepanenko and Lykossov, (2005) and Stepanenko et al., (2011) and then extensively validated against biogeochemical observations and similar type models as a part of the Lake Model Intercomparison Project (Stepanenko et al., 2010, 2013, 2016). In recent studies, the main focus of the LAKE model developments was its biogeochemical module, which describes $\mathrm{O}_{2}, \mathrm{CO}_{2}$ and $\mathrm{CH}_{4}$ gas exchange between the water column and sediments at different depths (Stepanenko et al., 2011; Iakunin et al., 2020). In spite of the considerable research testing the

60 LAKE biogeochemical module, little has been done to validate water temperatures produced by the LAKE model for lakes in permafrost regions, rendering it difficult to predict the heat fluxes and impact to underlying frozen ground.

Here we validate the LAKE model thermodynamics using water temperature observations from three Arctic lakes in Alaska: Fox Den, Atqasuk, and Toolik. All three lakes are located within the continuous permafrost zone in the northern part of Alaska (Jorgenson et al., 2008; Obu et al., 2019). The lakes represent three different climate regimes spanning the continuous permafrost

65 zone, ranging from -6 to $-12{ }^{\circ} \mathrm{C}$ mean annual air temperatures (MAAT). The morphometry of the lakes varies from small and shallow (Fox Den) to large and deep (Toolik). Validating lake water temperatures among diverse climatological conditions and lake morphometries in the Arctic allows us to quantify the robustness of the LAKE model. This is a crucial step toward applying the LAKE model to examine the impact of water bodies on permafrost.

\section{Methods}

\section{$70 \quad 2.1$ Description of the model}

The LAKE 2.0 is a 1-D model of thermodynamic, hydrodynamic and biogeochemical processes in the water basin and the lake bottom sediments Stepanenko et al. (2016). The model uses the generic form of the Reynolds-averaged advection-diffusion equation applied to horizontal velocity components, temperature, turbulent kinetic energy (TKE), TKE dissipation, and concentration of multiple gases such as $\mathrm{O}_{2}, \mathrm{CO}_{2}$ and $\mathrm{CH}_{4}$. The lake thermodynamics includes a heat diffusion formulation where

75 heat conductance is a sum of molecular and turbulent coefficients computed involving the k-eps model (Stepanenko et al., 2016). The lake hydrodynamics portion employs momentum equations and uses the Coriolis force for lakes with a horizontal size that exceeds the internal Rossby deformation radius (Patterson et al., 1984). The model takes into account heat and gas exchange with a sloping bottom. The scheme for water temperature and gas concentrations is coupled to sediment columns originating at the bottom at different depths. The heat exchange in the sediment layer includes vertical transport and phase transition between

80 water and ice (Stepanenko et al., 2019). The vertical heat transport in sediments is described according to Côté and Konrad (2005). Liquid water is transported via gravity and capillary-sorption forces (Stepanenko and Lykossov, 2005). The geothermal heat flux at the lower boundary of the sediment layer is assumed to be zero. More detailed information about mathematical formulations used in the model can be found in Stepanenko and Lykossov (2005), Stepanenko et al. (2016) and Stepanenko et al. (2020). 


\subsection{LAKE model setup}

The simulation conducted in the present study spans 2, 4, and 4 years at three study lake sites (Atqasuk, Fox Den, and Toolik) respectively, with a 1 hour time step ( 1 day for Fox Den) for the input and output data. In the set-up stage, specific features of the study lakes were prescribed, namely the depth of the lake, area of lake surface, morphometry of the lake bottom, the vertical water grid resolution $(1 \mathrm{~m})$, the vertical soil grid resolution $(1 \mathrm{~m})$ and depth $(10 \mathrm{~m})$, and soil type (silty loam). The LAKE model was initialized with water column temperature data measured at each site. For each site, the model was spun up using 1 year of meteorological data repeated for 10 years. The resulting water and soil temperatures were used to initialize water and soil temperatures for the simulations. Atmospheric forcing input data were taken from local meteorological stations (Toolik, Atqasuk), remote meteorological stations (Fox Den) and remotely sensed satellite data (Fox Den, Atqasuk).

\subsection{Input data}

95 Since the LAKE model input files require a certain data format, we developed pre-processing scripts to streamline the LAKE model's input data. For Atqasuk, snow depth $(\mathrm{m})$ was converted to precipitation ( $\mathrm{m} \mathrm{s}^{-1}$, method described below). For Fox Den and Atqasuk incoming longwave and shortwave radiation were taken from NASA CERES for the $1^{\circ} \times 1^{\circ}$ grid cell containing the study lake (Wielicki et al., 1998; Rutan et al., 2015; Kato et al., 2018).

\subsection{Data and script availability}

100 Weather data and model infiles for simulations in this study have been archived and are publicly available (Jafarov et al., 2021). Observed water temperature data has been published and archived for Atqasuk (Hinkel et al., 2012), Fox Den (Jones et al., 2021), and Toolik Lake (MacIntyre and Cortes, 2017; Clark and Jafarov, 2021). Pre-processing scripts were developed to combine data sources, convert units, and format meteorological data for input into the LAKE model. Post-processing scripts were developed to compare LAKE modeled water temperature to observed water temperature and to calculate model error. All processing scripts have been archived and are publicly available (Clark and Jafarov, 2021).

\subsection{Study site: Atqasuk Lake}

Atqasuk Lake 201 (70.452497, -156.951984) is located on the North Slope of Alaska, approximately $90 \mathrm{~km}$ south of Utqiagvik, AK. It is a large lake $\left(2,732,050 \mathrm{~m}^{2}\right)$ with a maximum depth of $2.54 \mathrm{~m}$ surrounded by sedge, moss, dwarf-shrub wetland tundra (Walker et al., 2005). The area is classified as continuous permafrost, but the presence and depth of permafrost under the lake is

110 not confirmed (Jorgenson et al., 2008; Obu et al., 2019). Meteorological data was measured locally at the lake except for frozen season precipitation. Mean annual air temperature was $-8.98{ }^{\circ} \mathrm{C}$. Validation water temperatures were measured hourly at $30 \mathrm{~cm}$ and $250 \mathrm{~cm}$ for 2013 to 2015 (Hinkel et al., 2012). The simulation period was 2013-08-12 to 2015-08-10 (Fig. A1).

We pre-processed meteorological data for the Atqasuk lake from two sources: the South Meade USGS meteorological station and the Atqasuk lake meteorological station (Urban, 2017; Hinkel et al., 2012). The local meteorological data included:

115 atmospheric pressure $[\mathrm{mb}]$, rainfall $[\mathrm{mm}]$, air temperature $\left[{ }^{\circ} \mathrm{C}\right]$, wind speed $\left[\mathrm{m} \mathrm{s}^{-1}\right]$, gust speed $\left[\mathrm{m} \mathrm{s}^{-1}\right]$, wind direction $[$ degree], and short and longwave radiation $\left[\mathrm{W} \mathrm{m}^{-1}\right]$. The Atqasuk lake meteorological station did not have frozen season precipitation data. For frozen season precipitation we used hourly snow depth data from the South Meade USGS station (Urban, 2017). We extracted frozen precipitation from hourly snow depth by calculating the difference between the original and lagged snow depth time-series. Only positive differences were used for frozen precipitation. Due to sonic ranger instrument noise and wind-blown snow, the differenced time series contained high frequency small positive values that did not correspond to actual precipitation amounts. To filter this noise from the precipitation signal, we experimented with different minimum frozen precipitation 
threshold values and found that filtering precipitation values to remove values $<2.5 \mathrm{~cm}$ provides the best to match the observed lake water temperatures.

\subsection{Study site: Fox Den Lake}

125 Fox Den Lake $(66.55877,-164.45670)$ is located on the Northwest portion of the Seward Peninsula in Western Alaska. It is a small lake $\left(17,861 \mathrm{~m}^{2}\right)$ approximately $2 \mathrm{~km}$ from the Chukchi Sea coast, located in a drained lake basin with a maximum depth of $1.6 \mathrm{~m}$, and surrounded by tussock sedge, dwarf-shrub, moss tundra (Walker et al., 2005). The area is classified as continuous permafrost, but the presence and depth of permafrost under the lake is not confirmed (Jorgenson et al., 2008; Obu et al., 2019). Meteorological data was not available locally at Fox Den. Instead, meteorological data from the National Weather Service

130 station (Smith et al., 2011) at Kotzebue, AK ( 90km ENE, station ID: 70133026616) was used and short and longwave radiation was obtained from NASA CERES (Wielicki et al., 1998; Rutan et al., 2015). Mean annual air temperature at Kotzebue was -5.37 ${ }^{\circ} \mathrm{C}$ for 2009 to 2013 . Validation water temperatures were measured hourly at $1.5 \mathrm{~m}$ for 2009-2013 (Jones et al., 2021). The simulation period was 2009-06-10 to 2013-06-10 (Fig. A2).

\subsection{Study site: Toolik Lake}

135 Toolik Lake $(68.63150,-149.60740)$ is located on the North Slope of Alaska. It is a large and deep lake $\left(1,492,898 \mathrm{~m}^{2}\right)$ with a maximum depth of $26.5 \mathrm{~m}$ surrounded by non-tussock sedge, dwarf-shrub, moss tundra and prostrate dwarf-shrub, herb tundra (Walker et al., 2005). The lake has a seasonal inlet and outlet. The area is classified as continuous permafrost, but the presence and depth of permafrost under the lake is not confirmed (Jorgenson et al., 2008; Obu et al., 2019). Meteorological data is collected at the nearby $(\sim 30 \mathrm{~m} \mathrm{~W})$ Toolik Field Station and includes atmospheric pressure [mb], all season precipitation [mm],

140 snow depth $[\mathrm{m}]$, air temperature $\left[{ }^{\circ} \mathrm{C}\right]$, wind speed $\left[\mathrm{m} \mathrm{s}^{-1}\right]$, wind direction [degrees], and short and longwave radiation $\left[\mathrm{W} \mathrm{m}{ }^{-1}\right]$ (Edgar et al., 2018). Mean annual air temperature at Toolik was $-7.36{ }^{\circ} \mathrm{C}$. The simulation period was 2013-05-17 to 2016-09-18 (Fig. A3).

Validation water temperatures were measured at 5 min intervals for 2013-2016 (MacIntyre and Cortes, 2017). The temperature sensors at Toolik lake were placed at 24 depths from $0 \mathrm{~m}$ to $20 \mathrm{~m}$ for the ice-free season (June - August) and at 19 depths from 3

$145 \mathrm{~m}$ to $22 \mathrm{~m}$ for the ice season (September - May). For shallow depths $(0-2 \mathrm{~m})$, measured temperature was only available for the ice-free season, generally June through August. As water temperature measurement depths changed seasonally and annually, we interpolated the temperature data to hourly time intervals and $1 \mathrm{~m}$ depth intervals to compare with the model output data format. Inlet stream discharge and temperature were measured during the thaw season continuously using a pulse generator and stagedischarge relationships developed using periodic manual discharge measurements (Kling, 2019). Toolik inlet discharge data was

150 formatted for the LAKE model but no processing or unit conversions were performed (Clark and Jafarov, 2021). Lake outlet discharge was assumed to be equal to inlet discharge for model input.

Toolik lake meteorological data was provided in a raw format with missing data and without error checking. For our purposes, Toolik lake meteorological data was gap-filled using a 7-day rolling average (Clark and Jafarov, 2021). Data was manually checked for errors and missing or erroneous values were replaced. Missing atmospheric pressure data for the winter of

155 2015/2016 was filled with data from winter 2014/2015. Missing precipitation values were filled with 0.

\subsection{Model Sensitivity Analysis}

To test the sensitivity of the model output to potential future weather conditions and to test the 
model's sensitivity to inaccurate weather inputs, we altered the weather input for each lake using a common set of scenarios. We choose the following scenarios: precipitation (P, $-50 \%,-20 \%,-10 \%,+10 \%,+20 \%,+100 \%)$, frozen precipitation ( $\mathrm{P}_{-} \mathrm{w}$, -

$16020 \%,+20 \%$ ), shortwave radiation (SW, $-20 \%,-10 \%,+10 \%,+20 \%$ ), and air temperature $\left(\mathrm{TA},-2{ }^{\circ} \mathrm{C},-1{ }^{\circ} \mathrm{C},+1{ }^{\circ} \mathrm{C},+2{ }^{\circ} \mathrm{C}\right.$ ). The frozen season was defined as days with mean daily temperature $<0{ }^{\circ} \mathrm{C}$. Scenario data was compared to baseline simulations using the Z-score. Z-score is calculated as the mean of $Z$ 's for the scenario for a given model variable (e.g. water temperature at $1 \mathrm{~m}$ depth), where each $Z$ is calculated as the difference of the model variable, $x$, and the mean of baseline, $\mu$, divided by the standard deviation of the baseline, $\sigma$, following Eq. (1):

$165 Z=\frac{x-\mu}{\sigma}$.

\section{Results}

\subsection{Model validation: Atqasuk Lake}

The Atqasuk modeled lake temperatures closely follow the observed temperatures at $0.3 \mathrm{~m}$ and $2.5 \mathrm{~m}$ over the summer period (Fig. 1). During the frozen season, the modeled temperatures underestimate cooling in the lake. There is mismatch towards the end of each frozen season which is likely explained by ice rafting moving the temperature sensor into shallower water, which has been observed at many Arctic lakes (Jones, personal communication). After ice-off and temperature sensor replacement, the model captures summer temperatures well. A better match between modeled and observed temperature could be achieved with more accurate snow accumulation data and a well anchored temperature sensor.

a

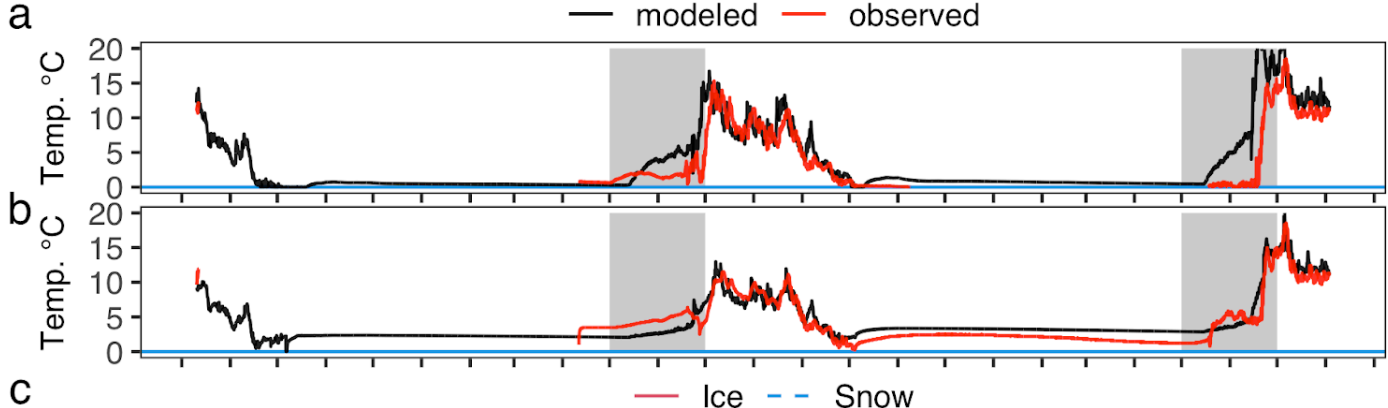

C

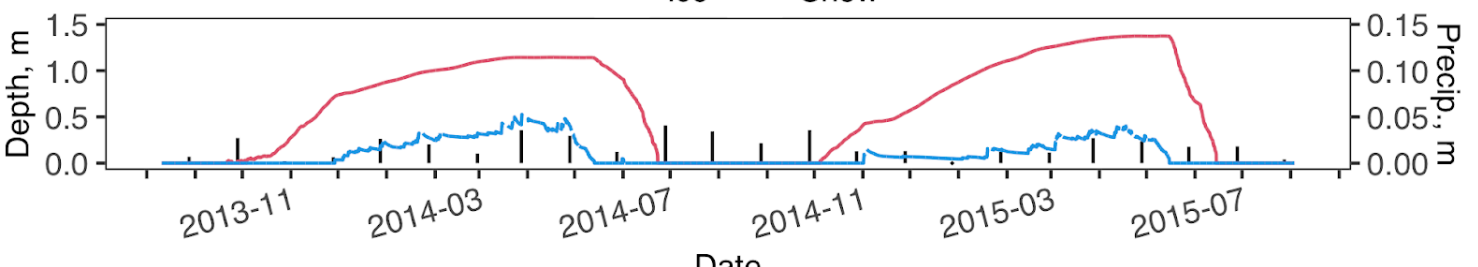

175 Figure 1. Atqasuk modeled and observed lake water temperature at $0.3 \mathrm{~m}$ (a) and $2.5 \mathrm{~m}$ (b) and modeled lake ice depth, lake snow depth and measured monthly precipitation (vertical black bars) (c). Gray shading indicates periods of uncertainty in temperature sensor depth when ice-rafting may have moved the sensor to shallower water. The $y$-axis of panel (a) is limited to water temperatures $>$ $0{ }^{\circ} \mathrm{C}$ as the LAKE model water temperature is limited to $>0{ }^{\circ} \mathrm{C}$.

\subsection{Model validation: Fox Den}

180 The modeled temperatures at Fox Den follow the observed temperatures (one depth: $1.5 \mathrm{~m}$ ) over the simulation period (Fig. 2). There is some temperature mismatch during ice-off and during the thaw season. As with Atqasuk, the temperature sensor at Fox 
Den was subject to ice raft induced movement during ice-off. Additionally, more accurate modeled temperatures may have been achieved with local meteorological data and a well anchored temperature sensor.

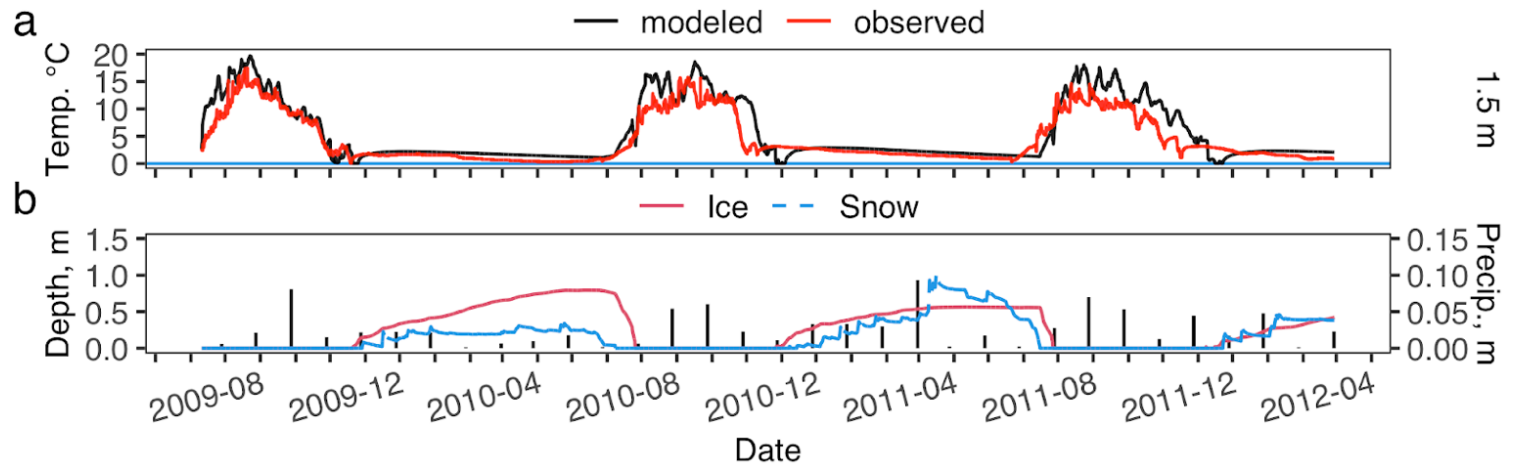

185 Figure 2. Fox Den Lake modeled and observed water temperature at $1.5 \mathrm{~m}$ (a) and modeled lake ice depth, modeled lake snow depth and measured monthly precipitation (vertical black bars) (b).

\subsection{Model validation: Toolik Lake}

Modeled water temperature was very similar to observed water temperature for Toolik Lake for all years (Fig. 3). For 2013 and 2014 the modeled shallow $(0,3 \mathrm{~m})$ water temperature was overestimated while for 2015 and 2016 shallow water temperature was underestimated, though it tracked observed temperature. At $3 \mathrm{~m}$ depth, summer water temperature was also overestimated in 2013 and 2014 and underestimated for 2015 and 2016. Frozen season $3 \mathrm{~m}$ water temperature for 2013/2014, 2014/2015, and 2015/2016 was underestimated. For both $0 \mathrm{~m}$ and $3 \mathrm{~m}$ depth, a step-like dip associated with ice-off and beginning of stream discharge data is seen in the modeled temperature, but not in observed data. From 2015-08 through 2015-09 at 3m depth, the observed water temperature appears to be in error, as the temperature departure is not seen at other depths. It was apparently corrected in mid- 2015-09 with the placement of the winter sensor array.

a - modeled - observed

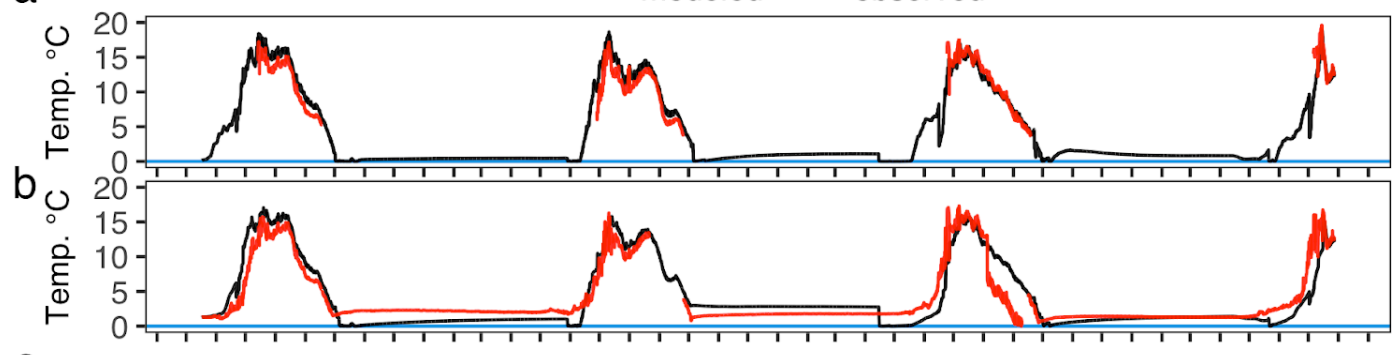

C - Ice - Snow

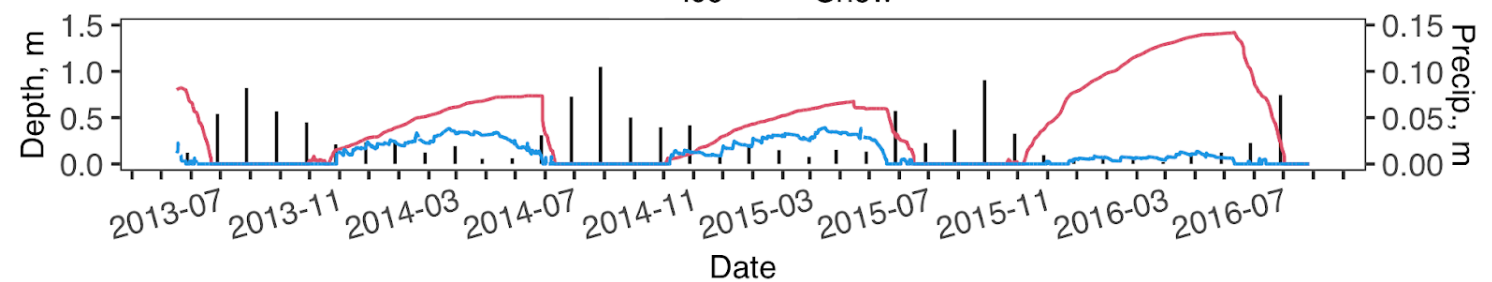

Figure 3. Toolik Lake modeled and observed lake water temperature at $1 \mathrm{~m}$ (a) and $3 \mathrm{~m}$ (b) and modeled lake ice depth, lake snow depth and measured monthly precipitation (vertical black bars) (c). Missing observed data in (a) and (b) is due to seasonal placement and removal of the temperature sensors, see Methods for details. The $\mathrm{y}$-axis of panel (a) is limited to water temperatures $>0{ }^{\circ} \mathrm{C}$ as the 
For $10 \mathrm{~m}$ and $19 \mathrm{~m}$ depths, modeled water temperature at Toolik tracked the general patterns of observed temperatures with some departures (Fig. 4). For $10 \mathrm{~m}$ and $19 \mathrm{~m}$ summertime water temperature, the model only partially captures the observed temperature patterns. As with $2 \mathrm{~m}$ and $3 \mathrm{~m}$, a step-like dip associated with ice-off and beginning of stream discharge data is seen in the modeled temperature, but not in observed data.

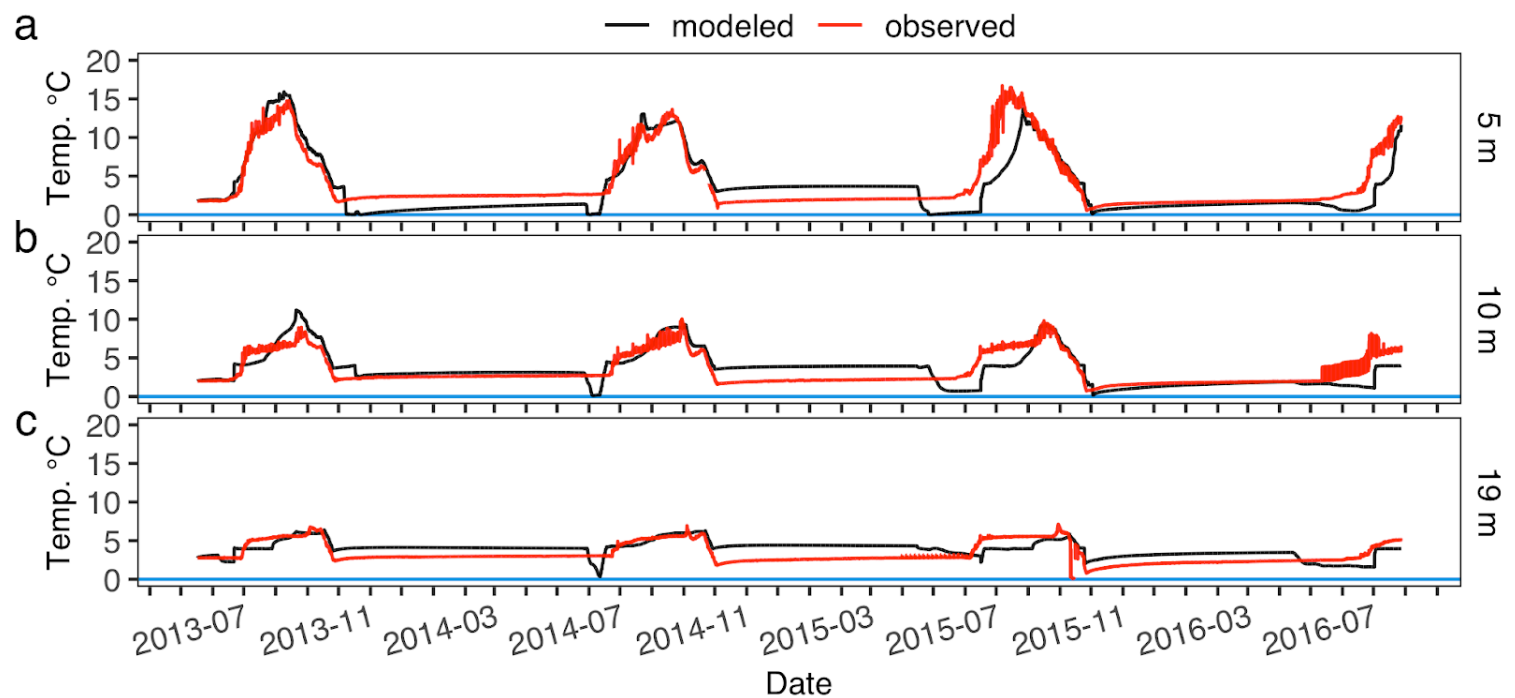

Figure 4. Toolik Lake modeled and observed lake water temperature at $5 \mathrm{~m}$ (a), $10 \mathrm{~m}$ (b) and $19 \mathrm{~m}$ (c).

\subsection{Sensitivity analysis}

The sensitivity scenarios (TA, P, P_w, and SW) had minimal effect on water temperature (2.5 m depth) for Atqasuk (-0.13 to $0.12 \mathrm{Z}$-score, Fig. 5). For Fox Den, the effect on water temperature (1.5 m depth) was minimal and similar to Atqasuk. For

210 Toolik, there were slightly larger positive Z-scores for shallow depth water temperatures $(1,3$, and $5 \mathrm{~m}$ depth, -0.13 to 0.34$)$ and also for deeper depths (10 and $19 \mathrm{~m}$ depth, -0.13 to 0.52) compared to the other two lakes. For all three lakes, shortwave radiation had the greatest effect followed by air temperature and precipitation with a few exceptions (Fig. 5 ), most notably P_50\% and $\mathrm{TA}+2 \mathrm{C}$.

Ice thickness showed moderate effects from the sensitivity scenarios for Fox Den (-0.73 to 1.08), but only minimal effects for

215 Atqasuk and Toolik (-0.41 to 0.49, Fig. 5). The P_50\% scenario had the greatest effect on increasing ice thickness for all three lakes while the P_200\% scenario had the greatest effect for decreasing ice thickness but only for Atqasuk and Fox Den. Ice thickness is strongly influenced by snow depth, particularly in the extreme precipitation scenarios.

Snow thickness was most strongly affected by the $\mathrm{P}$ scenarios for all lakes (Fig. 5). As expected, the extreme scenarios (P_50\% and P_200\%) had the greatest effect on snow depth. Increasing P, decreasing SW, and decreasing TA all increased snow depth; decreasing P, increasing SW, and increasing TA all decreased snow depth. Compared to year-round precipitation (P) scenarios, frozen season precipitation ( $\left.\mathrm{P}_{-} \mathrm{w}\right)$ scenarios were similar for water temperature, ice thickness, and snow depth (Fig. 5). 


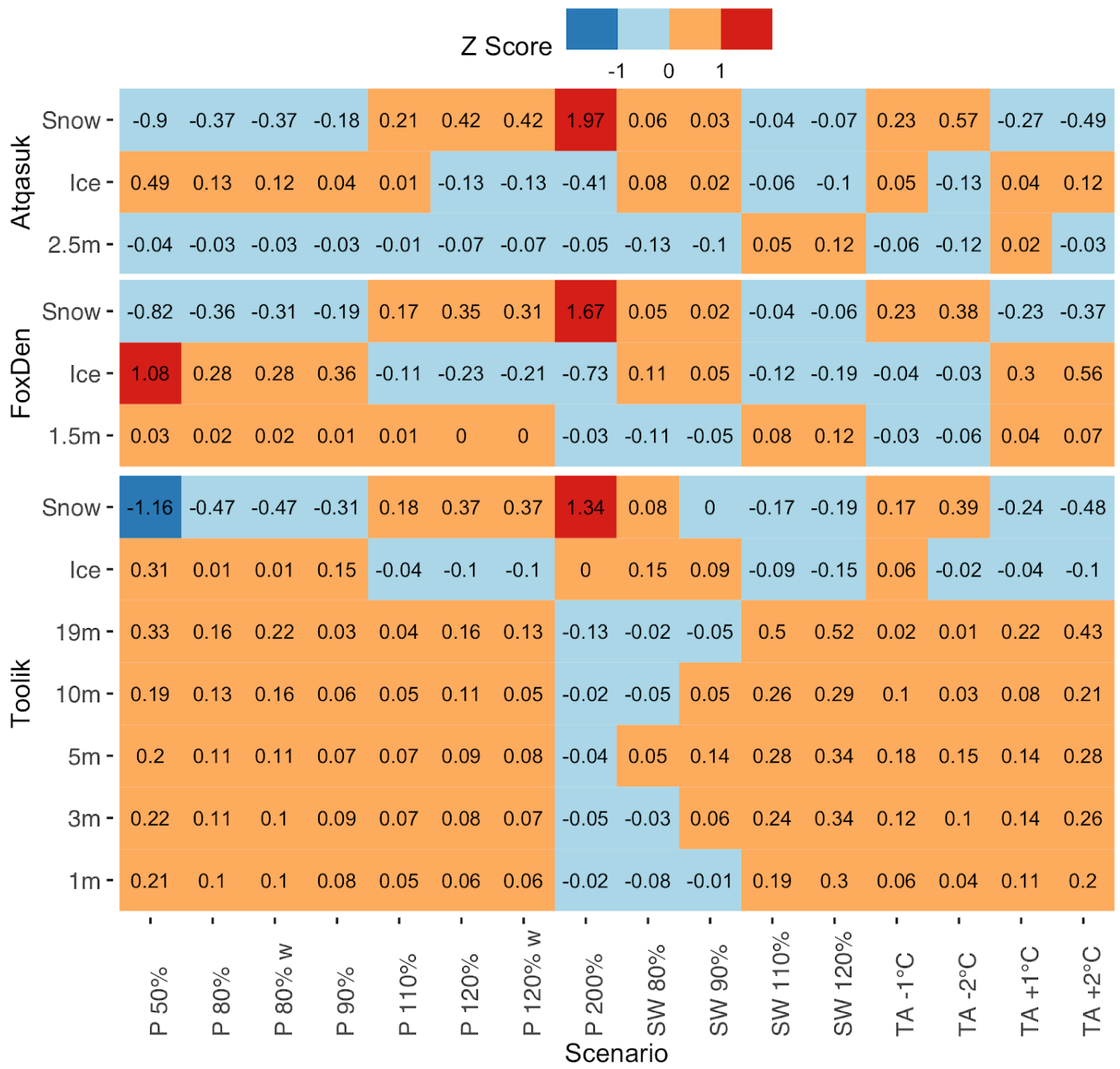

Figure 5. Model sensitivity matrix showing mean Z-score for each scenario compared to the baseline model scenario for each response variable (ice thickness $(\mathrm{m})$, snow depth $(\mathrm{m})$, and water temperature at various depths). The sensitivity scenarios are: precipitation (P, -

$225 \mathbf{5 0} \%,-\mathbf{2 0} \%,-\mathbf{1 0} \%,+\mathbf{1 0} \%,+\mathbf{2 0} \%,+\mathbf{1 0 0} \%)$, frozen precipitation $(\mathrm{P} w,-\mathbf{2 0} \%,+\mathbf{2 0} \%)$, shortwave radiation $(\mathrm{SW},-\mathbf{2 0} \%,-\mathbf{1 0} \%,+\mathbf{1 0} \%,+\mathbf{2 0} \%)$, and air temperature (TA, $-2{ }^{\circ} \mathrm{C},-1{ }^{\circ} \mathrm{C},+1{ }^{\circ} \mathrm{C},+2{ }^{\circ} \mathrm{C}$ ). Warm colors represent positive Z-scores, while cool colors represent negative $\mathrm{Z}$ scores. Lighter colors indicate smaller Z-scores while darker colors indicate greater Z-scores.

Focusing on the sensitivity of water temperatures during the frozen and thawed season, we find that most of the scenarios had a greater effect in the frozen season (Fig. 6). Increased SW scenarios had positive Z-scores for all three lakes, with greater Z-scores

230 in the frozen season. In general, Z-scores for Atqasuk were negative for most scenarios (except SW increases) and Z-scores were positive for Fox Den and Toolik for most scenarios ( except SW decreases for both lakes and TA decreases for Fox Den). The larger effect of the $\mathrm{P}$ scenarios in the frozen season can be attributed to snow cover thickness playing a large role in controlling frozen season lake water temperature. 
https://doi.org/10.5194/gmd-2022-9

Preprint. Discussion started: 28 January 2022

(c) Author(s) 2022. CC BY 4.0 License.

(c) (i)

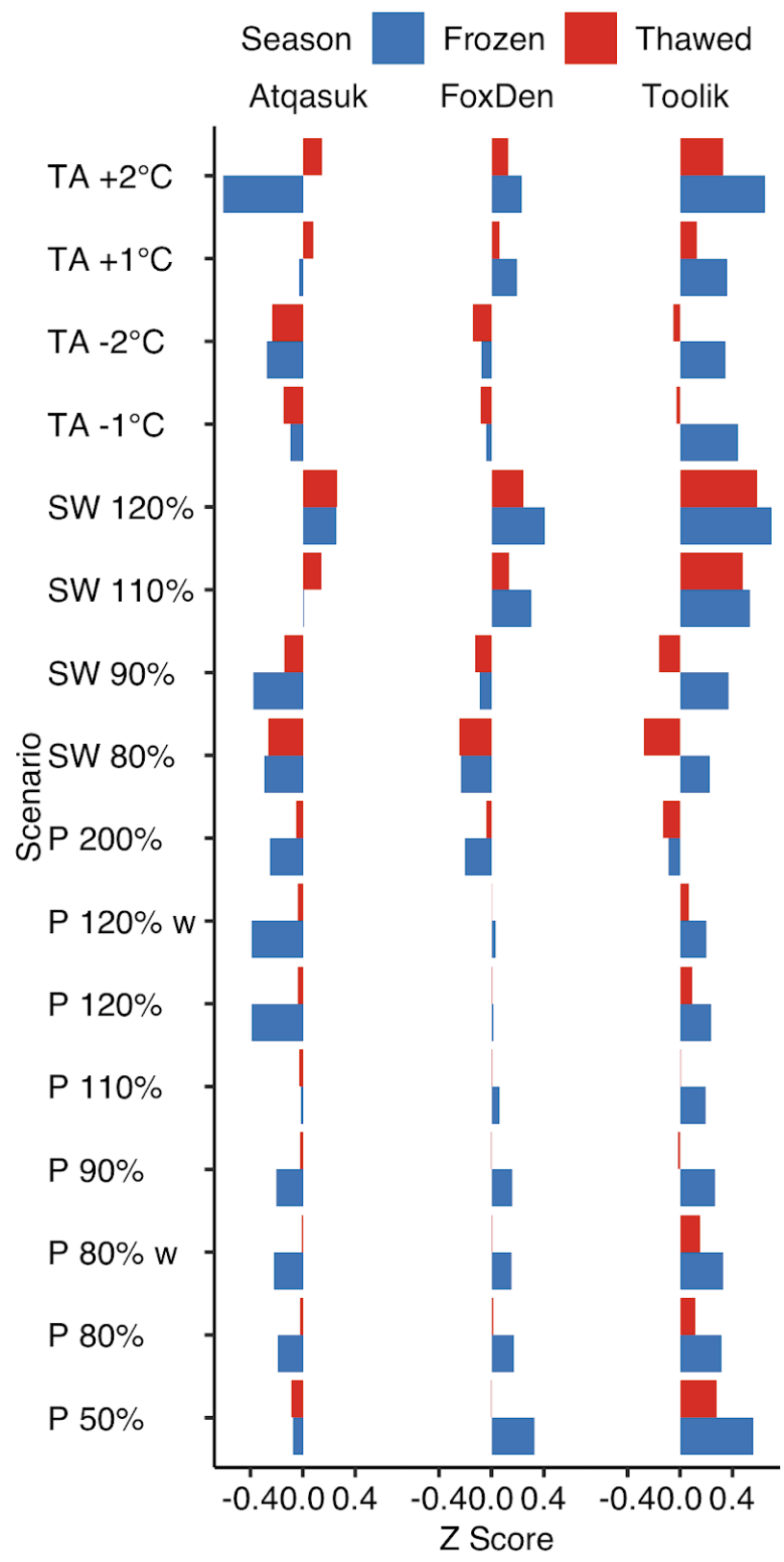

235 Figure 6. Model water temperature response (mean z-score, all water depths) across the three lakes, 16 scenarios, and two seasons (frozen and thawed, based on ice presence) as compared to the baseline scenario. Blue bars are the frozen season, red bars are the thawed season. See Methods or Fig. 5 for description of the scenarios.

\section{Discussion}

\subsection{Differences between study lakes}

240 Despite large differences in lake size, shape, depth, and meteorology, the LAKE model performed well in reproducing lake water temperatures in all three study lakes. Toolik Lake is a large and deep lake compared to the shallow small Fox Den and the 
shallow but large Atqasuk lake. Toolik lake also has a large inlet and outlet stream which contributes substantial water influx and efflux during the thaw season.

Initially, we attempted to model Toolik Lake without including inflow and outflow but we were unable to achieve good matches

245 with measured lake temperatures (Figs. B1 \& B2). Most notably, water temperature mixing in the profile was delayed and weaker during the period of ice-off and throughout the summer. Modeled shallow water $(1 \mathrm{~m})$ temperature exceeded the observed temperatures and modeled deep water temperatures remained warmer than observed water temperatures during the frozen season and colder during the thawed season. Incorporating inflow and outflow into the Toolik simulations greatly improved the model fit to the observed temperature data. Most notably inflows after ice-off helped to promote vertical mixing of

250 the temperature profile.

The discharge data used for Toolik lake was only available for a limited period of time during the thawed season. Discharge measurements did not start until personnel arrived with discharge equipment (mid-May to early-June). Discharge measurements from the early thaw season (likely beginning in early-May) are missing. This type of partial dataset highlights the need to collect data on ecological timeframes (i.e. the full thaw and full discharge season).

\section{4.2 Differences between terrestrial and lake based met stations}

There was minimal mismatch between modeled lake water temperatures and measured lake water temperatures for all three lakes. The errors in modeled lake temperatures can be partially attributed to the quality of the meteorological data used to drive the LAKE model, particularly for frozen season precipitation. Furthermore, all meteorological data used in this study was collected from terrestrial stations (at various distances), not from the lake surfaces, further adding to potential modeled lake

260 temperature error.

It is well known that meteorological conditions on lakes differ from that of the nearby terrestrial surfaces due to differences in surface albedo, heat exchange, surface roughness, and fetch. Furthermore, it is common for Arctic lake snow cover to differ from terrestrial snow cover (Sturm and Liston, 2003) as high winds can and do remove the complete snowpack from frozen lakes many times during the frozen season. In addition, much of the snowpack may be converted to snow ice, effectively reducing the snow thickness (Leppäranta, 2014). Snowpack plays an important role in the surface energy balance of lakes (Jeffries and Morris, 2006; Jeffries et al., 1999). Arctic lakes without snowpack would have substantially greater ice thickness and lower water temperatures throughout the frozen season (Alexeev et al., 2016). We do not have validation data for lake snowpack for our three study lakes. In future studies, it would be worthwhile to test the ability of the model to produce this phenomenon and ideally recreate it for a known lake with a validation dataset of water temperature, lake ice thickness, and lake snow depth.

\section{$270 \quad 4.3$ Modeling lake thermal effects in permafrost}

While much work has been done in the study and simulation of lakes in permafrost settings, few studies have addressed the sensitivity of arctic lakes to climate change. Langer et al. (2016) simulated two lakes in the Lena River Delta using a linked CryoGrid3 and FLake model using historic climate data and two climate projections (Representative Concentration Pathway 4.5 $\& 8.5)$ to assess the effects of shallow water bodies on permafrost degradation in land surface models. However, their analysis

275 focuses on sediment temperatures, talik formation below the lakes, and formation of new waterbodies in thawing permafrost. Other studies have applied models to simulate hydrologic transport processes and pathways (Rueda and MacIntyre, 2010), carbon biogeochemistry and ebullition (Tan et al., 2015, 2017), lake thermal structure (Guo et al., 2021), and stratification and heat exchange (Boike et al., 2015) in Toolik Lake and other Arctic lakes. While several other models have been applied to simulate lake thermal dynamics in permafrost settings, they have focused on thermokarst shore expansion (Ling and Liao, 2016; 
280 Ling and Zhang, 2019), talik sediment temperatures, talik development, and refreezing (Ling and Zhang, 2003, 2004), lake ice phenology (Zhang and Jeffries, 2000; Morris et al., 2005), conductive heat flux through snow (Jeffries et al., 1999; Jeffries and Morris, 2006), or advective heat transport (Rowland et al., 2011) rather than lake water temperature, ice thickness and snow depth as in this study. Previous work has not addressed the sensitivity of lake water temperature, lake ice thickness or lake snow depth to changes in air temperature, precipitation, or shortwave radiation.

\section{4.4 Observed LAKE model dynamics}

The "dips" of water temperature in LAKE model results for Toolik lake down to depths of $10 \mathrm{~m}$ prior to ice-off can be explained by convective instability under the ice, where this instability can be caused by the under-ice penetration of solar radiation creating unstable stratification (a well-known phenomenon, e.g. Bouffard et al., 2019). However, the model significantly overestimated the magnitude of the process, which indicates likely numerical instabilities to be addressed in future studies.

The Z-scores in water temperature were limited in the model by negative feedbacks between surface temperature and surface heat budget components. The rise of surface temperature by increasing air temperature (TA scenarios) or shortwave radiation (SW scenarios) leads to enhancing upward longwave radiation and evaporative heat losses, hindering further temperature rise. A similar effect of suppressing the surface temperature departure from baseline simulation takes place under the opposite air temperature and shortwave radiation deviations. The applicability of this modeling result to real-world processes is limited by not taking into account the lake effects on atmospheric state, and in a fully coupled lake-atmosphere system model the similar sensitivity experiments should provide different estimates.

\section{Conclusion}

\subsection{Sensitivity analysis summary}

The sensitivity analysis shows us that the LAKE model is robust and not highly sensitive to the weather data perturbations used

300 in this study. Even the relatively extreme scenarios $\left(\mathrm{P}_{-} 50 \%, \mathrm{P}_{-} 200 \%, \mathrm{SW}_{-} 120 \%\right.$, TA_+2, and TA_-2) produced only moderate $\mathrm{Z}$-scores $<2.0$. More moderate scenarios produced minimal Z-scores, $<1.0$ in a majority of scenarios.

\subsection{Local vs remote met data for LAKE model}

Local meteorological data for the arctic is often lacking, of poor quality, or often contains large spans of missing data due to equipment failure and harsh weather conditions. Meteorological data for lakes is especially rare as the vast majority of meteorological stations are terrestrially located. We were encouraged by our Fox Den results that we were able to reasonably accurately model lake water temperatures with daily remote meteorological data and remotely sensed radiative fluxes. Future applications of the LAKE model will benefit from the abundance of daily meteorological data, remote meteorological data, and remotely sensed radiative fluxes.

\subsection{Application of RS for LAKE model}

310 Remote sensing has the potential to provide much needed local data for lake surface conditions including snow depth, ice thickness, and surface radiation fluxes. While we did not include remotely sensed snow depth or ice thickness in this study, such data would serve to better estimate and validate lake modeling efforts over large areas without local meteorological stations. However, care should be taken in applying remote sensing data without local validation datasets. The LAKE model could be 
used for the development of a reduced complexity model that could be applied in combination with the remotely sensed data to

315 evaluate the thermal impact of widespread Arctic lakes on thawing permafrost.

\subsection{Application of LAKE 2.0 in permafrost environments}

LAKE 2.0 is a robust model that is appropriate for modeling the thermal interaction of surface waters and permafrost that is widespread in Arctic landscapes. To the best of our knowledge, the sensitivity of lake thermal and ice regimes to perturbations of atmospheric forcing in the continuous permafrost zone has not been addressed in the literature. Sub-lake permafrost and talik development below shallow lakes are topics of interest as the Arctic continues to experience unprecedented warming, shifting lake thermal dynamics and thawing permafrost (e.g. Peng et al., 2021; Langer et al., 2016; Boike et al., 2015; Alexeev et al., 2016; Creighton et al., 2018; Parsekian et al., 2019; Arp et al., 2016; Lin et al., 2010). Empirical studies have already shown that shallow lakes have warmed substantially over the last 30 years and may have already begun talik development (Arp et al., 2016). LAKE 2.0 can be a valuable tool to explore the thermal effects of new and developing arctic lakes on underlying permafrost. 
Appendix A: Meteorological data used in simulations

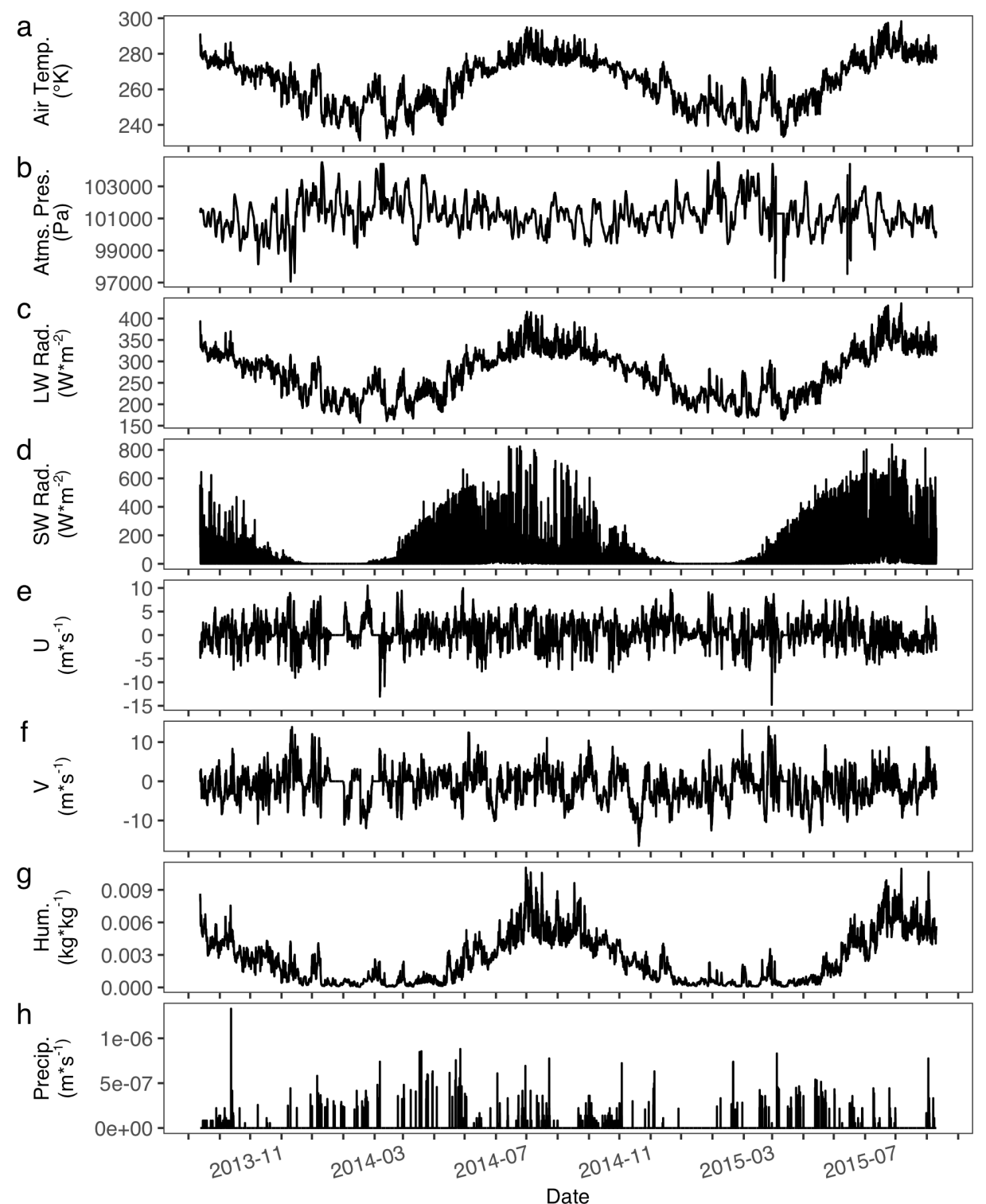

Figure A1. Atqasuk hourly meteorological data used in simulations. Air temperature ${ }^{\circ} \mathrm{K}$ (a), atmospheric pressure Pa (b), longwave 


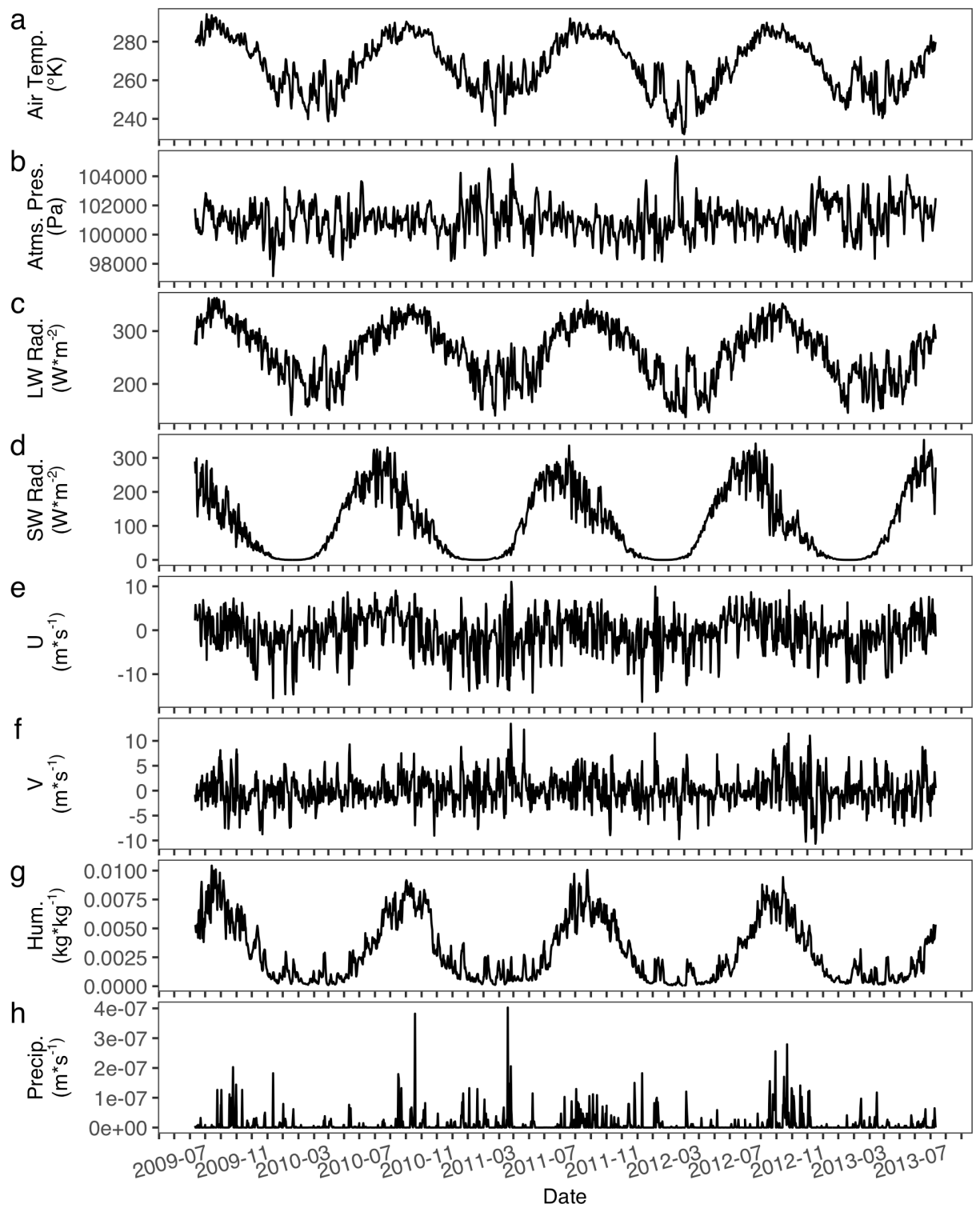

Figure A2. Fox Den daily meteorological data used in simulations. Air temperature ${ }^{\circ} \mathrm{K}(\mathrm{a})$, atmospheric pressure Pa (b), longwave radiation $\mathrm{W} \mathrm{m}^{2}(\mathrm{c})$, shortwave radiation $\mathrm{W} \mathrm{m}^{2}(\mathrm{~d}), 2$ component wind speed $\mathrm{m} \mathrm{s}^{-1}(\mathrm{e} \& \mathrm{f})$, humidity $\mathrm{kg} \mathrm{kg}^{-1}(\mathrm{~g})$, and precipitation $\mathrm{m} \mathrm{s}^{-1}$ (h). 


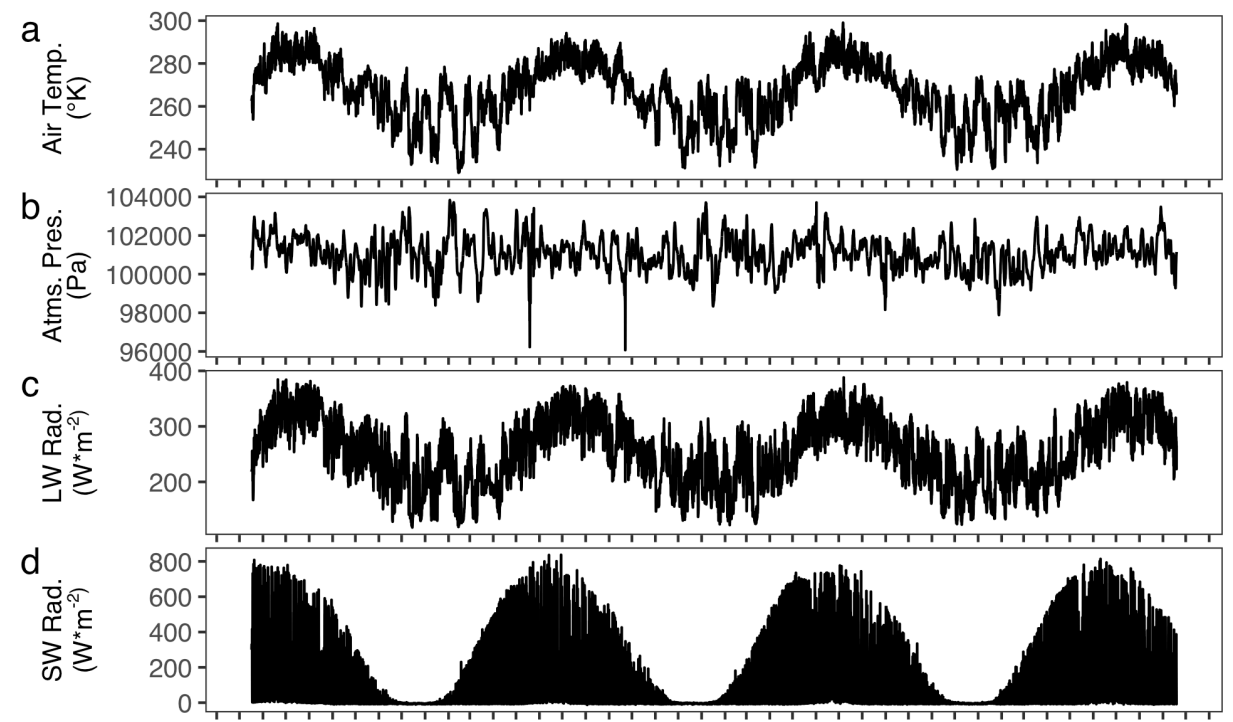

e

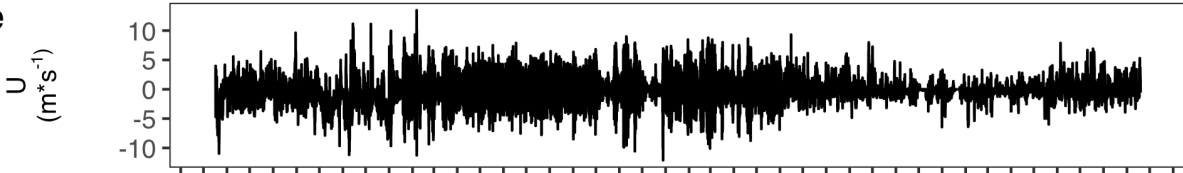

f

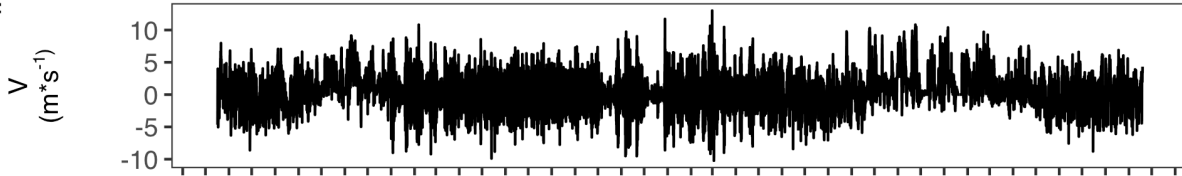

9

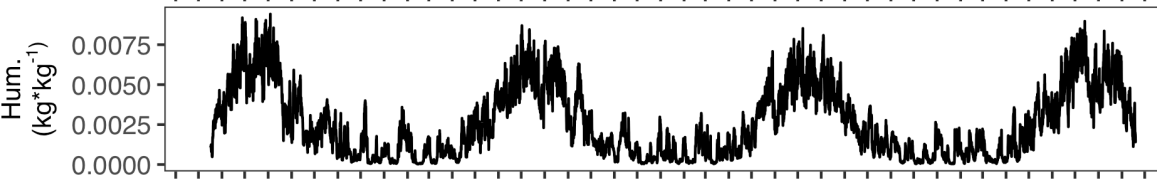

$\mathrm{h}$

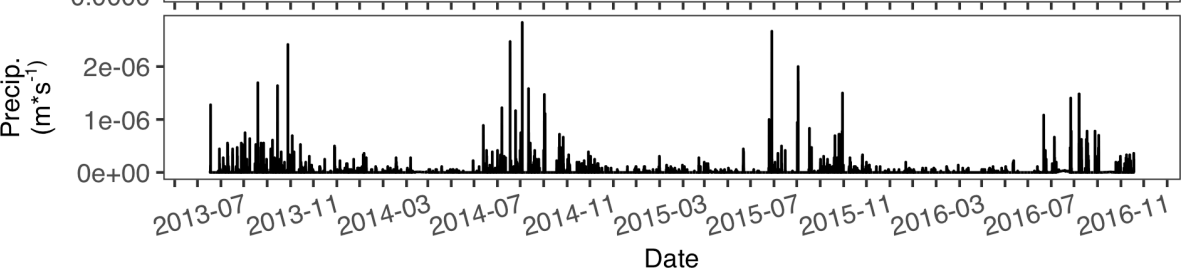

Figure A3. Toolik hourly meteorological data used in simulations. Air temperature ${ }^{\circ} \mathrm{K}$ (a), atmospheric pressure Pa (b), longwave radiation $\mathrm{W} \mathrm{m}^{2}(\mathrm{c})$, shortwave radiation $\mathrm{W} \mathrm{m} \mathrm{m}^{2}(\mathrm{~d}), 2$ component wind speed $\mathrm{m} \mathrm{s}^{-1}(\mathrm{e} \& \mathrm{f})$, humidity $\mathrm{kg} \mathrm{kg}^{-1}(\mathrm{~g})$, and precipitation $\mathrm{m} \mathrm{s}^{-1}$ (h). 
https://doi.org/10.5194/gmd-2022-9

Preprint. Discussion started: 28 January 2022

(c) Author(s) 2022. CC BY 4.0 License.

(c) (i)

Appendix B: Toolik Lake simulations without inflow and outflow

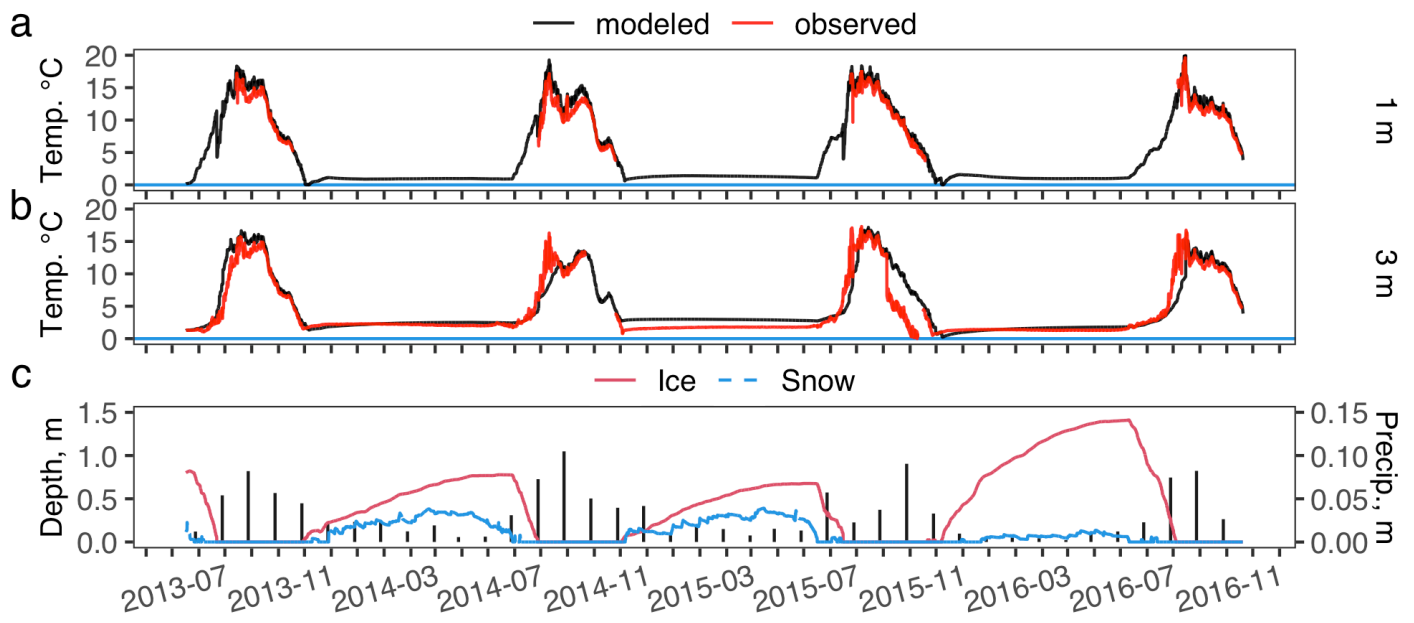

Date

Figure B1. Toolik modeled with no inflow and observed lake water temperature at $1 \mathrm{~m}$ (a) and $3 \mathrm{~m}$ (b) and modeled lake ice depth, lake snow depth and measured monthly precipitation (vertical black bars) (c). Missing observed data in (a) and (b) is due to seasonal placement and removal of the temperature sensors, see Methods for details.

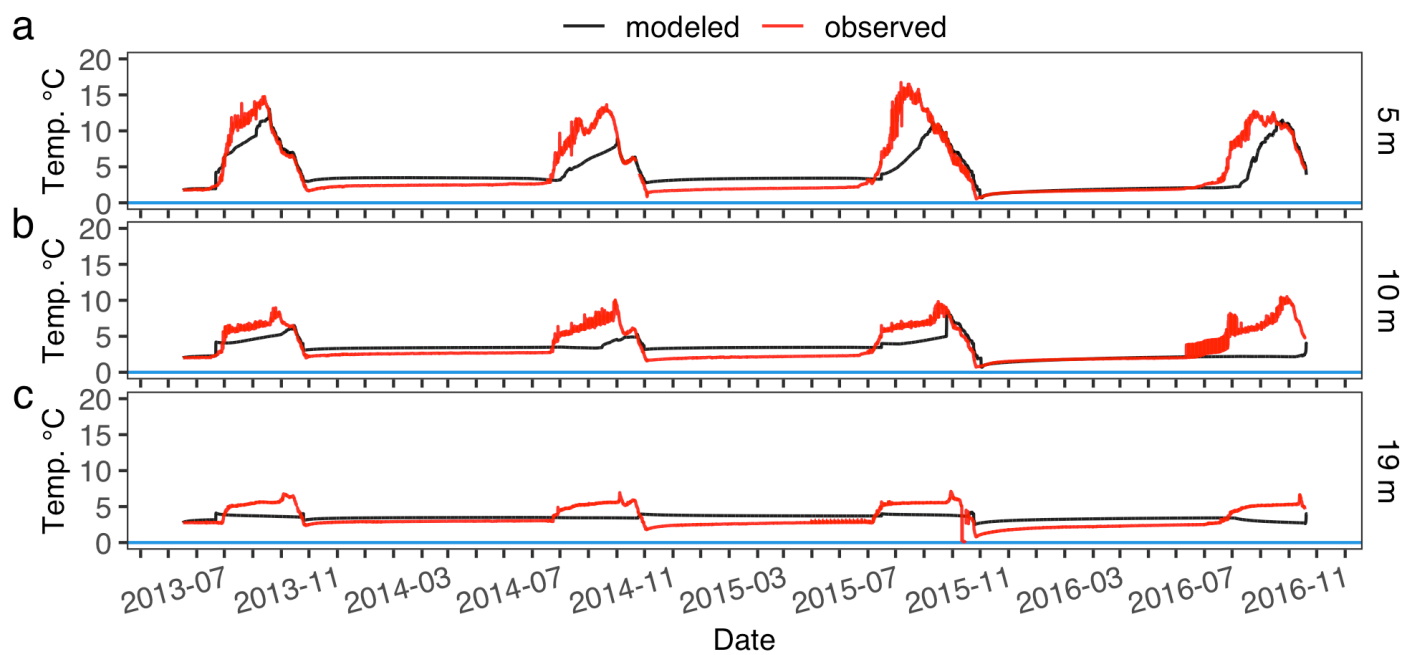

Figure B2. Toolik modeled with no inflow and observed lake water temperature at $5 \mathrm{~m} \mathrm{(a)}, 10 \mathrm{~m}$ (b) and $19 \mathrm{~m}$ (c).

\section{Code and data availability}

The atmospheric forcing data and model input files can be found at (Jafarov et al., 2021) or upon request from the corresponding author. The model outputs, validation datasets, and processing scripts can be found at (Clark and Jafarov, 2021) or upon request

350 from the corresponding author. The source code for the latest version of the LAKE 2.0 model is available at (http://tesla.parallel.ru/Viktor/LAKE/wikis/LAKE-model, Stepanenko et al., 2016). 


\section{Author contributions}

JC and EJ were responsible for the study design, numerical simulation setup, model runs, processing and analysis of the results. JC and EJ drafted the manuscript. JC, EJ, VS, KT, and BJ edited and revised the manuscript.

\section{Competing interests}

The authors declare that they have no conflict of interest.

\section{Acknowledgements}

JAC and KDT acknowledge NSF Award \#1850578. EEJ received support as part of the Interdisciplinary Research for Arctic Coastal Environments (InteRFACE) project through the Department of Energy, Office of Science, Biological and Environmental

Research (BER) Regional and Global Model Analysis (RGMA) program, awarded under contract grant \# 89233218CNA000001 to Triad National Security, LLC ("Triad"). VS acknowledges support from the Russian Ministry of Science and Higher Education (grant MD-1850.2020.5, and agreement 075-15-2019-1621). BMJ was supported by grants from the US National Science Foundation under award \#'s OPP-1850578, OPP-2114051, and OPP-1806213.

\section{References}

365 Abnizova, A., Siemens, J., Langer, M., and Boike, J.: Small ponds with major impact: The relevance of ponds and lakes in permafrost landscapes to carbon dioxide emissions, Global Biogeochemical Cycles, 26, https://doi.org/10.1029/2011GB004237, 2012.

Alexeev, V. A., Arp, C. D., Jones, B. M., and Cai, L.: Arctic sea ice decline contributes to thinning lake ice trend in northern Alaska, Environ. Res. Lett., 11, 074022, https://doi.org/10.1088/1748-9326/11/7/074022, 2016.

370 Arp, C. D., Jones, B. M., Urban, F. E., and Grosse, G.: Hydrogeomorphic processes of thermokarst lakes with grounded-ice and floating-ice regimes on the Arctic coastal plain, Alaska, 25, 2422-2438, https://doi.org/10.1002/hyp.8019, 2011.

Arp, C. D., Jones, B. M., Grosse, G., Bondurant, A. C., Romanovsky, V. E., Hinkel, K. M., and Parsekian, A. D.: Threshold sensitivity of shallow Arctic lakes and sublake permafrost to changing winter climate, Geophysical Research Letters, 43, 63586365, https://doi.org/10.1002/2016GL068506, 2016.

375 Boike, J., Georgi, C., Kirilin, G., Muster, S., Abramova, K., Fedorova, I., Chetverova, A., Grigoriev, M., Bornemann, N., and Langer, M.: Thermal processes of thermokarst lakes in the continuous permafrost zone of northern Siberia - observations and modeling (Lena River Delta, Siberia), Biogeosciences, 12, 5941-5965, https://doi.org/10.5194/bg-12-5941-2015, 2015.

Bouffard, D., Zdorovennova, G., Bogdanov, S., Efremova, T., Lavanchy, S., Palshin, N., Terzhevik, A., Vinnå, L. R., Volkov, S., Wüest, A., Zdorovennov, R., and Ulloa, H. N.: Under-ice convection dynamics in a boreal lake, Inland Waters, 9, 142-161, 380 https://doi.org/10.1080/20442041.2018.1533356, 2019.

Clark, J. A. and Jafarov, E. E.: LAKE 2.0_processing-scripts and data, Zenodo, https://doi.org/10.5281/zenodo.5593754, 2021.

Côté, J. and Konrad, J.-M.: A generalized thermal conductivity model for soils and construction materials, Can. Geotech. J., 42, 443-458, https://doi.org/10.1139/t04-106, 2005.

Creighton, A. L., Parsekian, A. D., Angelopoulos, M., Jones, B. M., Bondurant, A., Engram, M., Lenz, J., Overduin, P. P., 385 Grosse, G., Babcock, E., and Arp, C. D.: Transient Electromagnetic Surveys for the Determination of Talik Depth and Geometry Beneath Thermokarst Lakes, 123, 9310-9323, https://doi.org/10.1029/2018JB016121, 2018. 
Edgar, C., Cherry, J., Cohen, L., Haupert, C., Kade, A., Laundre, J., Dam, B. V., and McPherson, R.: Hourly meteorological data from Toolik Field Station, Alaska (1988-2017)., https://doi.org/10.18739/A2FJ29C5J, 2018.

Grant, L., Vanderkelen, I., Gudmundsson, L., Tan, Z., Perroud, M., Stepanenko, V. M., Debolskiy, A. V., Droppers, B., Janssen,

390 A. B. G., Woolway, R. I., Choulga, M., Balsamo, G., Kirillin, G., Schewe, J., Zhao, F., del Valle, I. V., Golub, M., Pierson, D., Marcé, R., Seneviratne, S. I., and Thiery, W.: Attribution of global lake systems change to anthropogenic forcing, Nat. Geosci., 14, 849-854, https://doi.org/10.1038/s41561-021-00833-x, 2021.

Grenier, C., Anbergen, H., Bense, V., Chanzy, Q., Coon, E., Collier, N., Costard, F., Ferry, M., Frampton, A., Frederick, J., Gonçalvès, J., Holmén, J., Jost, A., Kokh, S., Kurylyk, B., McKenzie, J., Molson, J., Mouche, E., Orgogozo, L., Pannetier, R.,

395 Rivière, A., Roux, N., Rühaak, W., Scheidegger, J., Selroos, J.-O., Therrien, R., Vidstrand, P., and Voss, C.: Groundwater flow and heat transport for systems undergoing freeze-thaw: Intercomparison of numerical simulators for 2D test cases, Advances in Water Resources, 114, 196-218, https://doi.org/10.1016/j.advwatres.2018.02.001, 2018.

Grosse, G., Jones, B., and Arp, C.: 8.21 Thermokarst Lakes, Drainage, and Drained Basins, in: Treatise on Geomorphology, edited by: Shroder, J. F., Academic Press, San Diego, 325-353, https://doi.org/10.1016/B978-0-12-374739-6.00216-5, 2013.

400 Guo, M., Zhuang, Q., Yao, H., Golub, M., Leung, L. R., Pierson, D., and Tan, Z.: Validation and Sensitivity Analysis of a 1-D Lake Model Across Global Lakes, Journal of Geophysical Research: Atmospheres, 126, https://doi.org/10.1029/2020JD033417, 2021.

Hinkel, K., Lenters, J., Arp, C., and Frey, K.: Collaborative Research: Toward a Circumarctic Lakes Observation Network (CALON)-- Multiscale observations of lacustrine systems, Arctic Data Center, 2012.

405 Iakunin, M., Stepanenko, V., Salgado, R., Potes, M., Penha, A., Novais, M. H., and Rodrigues, G.: Numerical study of the seasonal thermal and gas regimes of the largest artificial reservoir in western Europe using the LAKE 2.0 model, Geoscientific Model Development, 13, 3475-3488, https://doi.org/10.5194/gmd-13-3475-2020, 2020.

Jafarov, E., Clark, J., Piliouras, A., Tape, K., Jones, B., and Rowland, J.: The LAKE model input dataset for three Arctic lakes, ESS-DIVE: Deep Insight for Earth Science Data, 2021.

410 Jeffries, M. O. and Morris, K.: Instantaneous daytime conductive heat flow through snow on lake ice in Alaska, 20, 803-815, https://doi.org/10.1002/hyp.6116, 2006.

Jeffries, M. O., Zhang, T., Frey, K., and Kozlenko, N.: Estimating late-winter heat flow to the atmosphere from the lakedominated Alaskan North Slope, 45, 315-324, https://doi.org/10.3189/S0022143000001817, 1999.

Jones, B., Grosse, G., and Clark, J.: Fox Den Lake bed water temperature, Northwest Seward Peninsula, Alaska, 2009-2013,

415 Arctic Data Center, 2021.

Jorgenson, M., Yoshikawa, K., Kanevskiy, M., Shur, Y., Romanovsky, V., Marchenko, S., and Jones, B.: Permafrost Characteristics of Alaska, in: Proceedings of the ninth international conference on permafrost, Ninth international conference on permafrost, Fairbanks, AK, 121-122, 2008.

Jorgenson, M. T. and Shur, Y.: Evolution of lakes and basins in northern Alaska and discussion of the thaw lake cycle, Journal of

420 Geophysical Research: Earth Surface, 112, https://doi.org/10.1029/2006JF000531, 2007.

Jorgenson, M. T., Shur, Y. L., and Pullman, E. R.: Abrupt increase in permafrost degradation in Arctic Alaska, Geophys. Res. Lett., 33, L02503, https://doi.org/10.1029/2005GL024960, 2006.

Kato, S., Rose, F. G., Rutan, D. A., Thorsen, T. J., Loeb, N. G., Doelling, D. R., Huang, X., Smith, W. L., Su, W., and Ham, S.H.: Surface Irradiances of Edition 4.0 Clouds and the Earth's Radiant Energy System (CERES) Energy Balanced and Filled (EBAF) Data Product, 31, 4501-4527, https://doi.org/10.1175/JCLI-D-17-0523.1, 2018. 
Kirillin, G., Hochschild, J., Mironov, D., Terzhevik, A., Golosov, S., and Nützmann, G.: FLake-Global: Online lake model with worldwide coverage, Environmental Modelling \& Software, 26, 683-684, https://doi.org/10.1016/j.envsoft.2010.12.004, 2011.

Kling, G.: Toolik Lake Inlet discharge data collected during summers of 2010 to 2018, Arctic LTER, Toolik Research Station, Alaska., LTER Network Member Node, 2019.

430 Langer, M., Westermann, S., Boike, J., Kirillin, G., Grosse, G., Peng, S., and Krinner, G.: Rapid degradation of permafrost underneath waterbodies in tundra landscapes - Toward a representation of thermokarst in land surface models, 121, 2446-2470, https://doi.org/10.1002/2016JF003956, 2016.

Leppäranta, M.: Freezing of Lakes and the Evolution of their Ice Cover, Springer Science \& Business Media, 309 pp., 2014.

Lin, Z., Niu, F., Xu, Z., Xu, J., and Wang, P.: Thermal regime of a thermokarst lake and its influence on permafrost, Beiluhe

435 Basin, Qinghai-Tibet Plateau, 21, 315-324, https://doi.org/10.1002/ppp.692, 2010.

Ling, F. and Liao, Q.: SIMPLE MODEL FOR THERMAL REGIME OF PERMAFROST SURROUNDING AN EXPANDING THERMOKARST LAKE, 8, 115-122, 2016.

Ling, F. and Zhang, T.: Numerical simulation of permafrost thermal regime and talik development under shallow thaw lakes on the Alaskan Arctic Coastal Plain, 108, https://doi.org/10.1029/2002JD003014, 2003.

440 Ling, F. and Zhang, T.: Modeling study of talik freeze-up and permafrost response under drained thaw lakes on the Alaskan Arctic Coastal Plain, 109, https://doi.org/10.1029/2003JD003886, 2004.

Ling, F. and Zhang, T.: Simulating heat source effect of a thermokarst lake in the first 540 years on the Alaskan Arctic using a simple lake expanding model, Cold Regions Science and Technology, 160, 176-183, https://doi.org/10.1016/j.coldregions.2019.01.009, 2019.

445 MacIntyre, S. and Cortes, A.: Time series of water temperature, specific conductance, and oxygen from Toolik Lake, North Slope, Alaska, 2015-2016, https://doi.org/10.18739/A2Z892F91, 2017.

Mironov, D.: Parameterization of Lakes in Numerical Weather Prediction. Description of a Lake Model (No. 11), German Weather Service, Offenbach am Main, Germany, 2008.

Morris, K., Jeffries, M., and Duguay, C.: Model simulation of the effects of climate variability and change on lake ice in central

450 Alaska, USA, 40, 113-118, https://doi.org/10.3189/172756405781813663, 2005.

Obu, J., Westermann, S., Bartsch, A., Berdnikov, N., Christiansen, H. H., Dashtseren, A., Delaloye, R., Elberling, B., Etzelmüller, B., Kholodov, A., Khomutov, A., Kääb, A., Leibman, M. O., Lewkowicz, A. G., Panda, S. K., Romanovsky, V., Way, R. G., Westergaard-Nielsen, A., Wu, T., Yamkhin, J., and Zou, D.: Northern Hemisphere permafrost map based on TTOP modelling for 2000-2016 at $1 \mathrm{~km} 2$ scale, Earth-Science Reviews, 193, 299-316, https://doi.org/10.1016/j.earscirev.2019.04.023, 4552019.

Painter, S. L.: Three-phase numerical model of water migration in partially frozen geological media: model formulation, validation, and applications, Comput Geosci, 15, 69-85, https://doi.org/10.1007/s10596-010-9197-z, 2011.

Painter, S. L., Coon, E. T., Atchley, A. L., Berndt, M., Garimella, R., Moulton, J. D., Svyatskiy, D., and Wilson, C. J.: Integrated surface/subsurface permafrost thermal hydrology: Model formulation and proof-of-concept simulations, Water Resources

Research, 52, 6062-6077, https://doi.org/10.1002/2015WR018427, 2016.

Parsekian, A. D., Creighton, A. L., Jones, B. M., and Arp, C. D.: Surface nuclear magnetic resonance observations of permafrost thaw below floating, bedfast, and transitional ice lakes, 84, EN33-EN45, https://doi.org/10.1190/geo2018-0563.1, 2019.

Patterson, J. C., Hamblin, P. F., and Imberger, J.: Classification and dynamic simulation of the vertical density structure of lakes, Limnology and Oceanography, 29, 845-861, https://doi.org/10.4319/lo.1984.29.4.0845, 1984. 
465 Peng, E.-X., Sheng, Y., Hu, X.-Y., Wu, J.-C., and Cao, W.: Thermal effect of thermokarst lake on the permafrost under embankment, Advances in Climate Change Research, 12, 76-82, https://doi.org/10.1016/j.accre.2020.10.002, 2021.

Provost, A. M. and Voss, C. I.: SUTRA, a model for saturated-unsaturated, variable-density groundwater flow with solute or energy transport-Documentation of generalized boundary conditions, a modified implementation of specified pressures and concentrations or temperatures, and the lake capability, SUTRA, a model for saturated-unsaturated, variable-density groundwater

470 flow with solute or energy transport-Documentation of generalized boundary conditions, a modified implementation of specified pressures and concentrations or temperatures, and the lake capability, U.S. Geological Survey, Reston, VA, https://doi.org/10.3133/tm6A52, 2019.

Rouse, W. R., Douglas, M. S. V., Hecky, R. E., Hershey, A. E., Kling, G. W., Lesack, L., Marsh, P., Mcdonald, M., Nicholson, B. J., Roulet, N. T., and Smol, J. P.: Effects of Climate Change on the Freshwaters of Arctic and Subarctic North America, 11,

475 873-902, https://doi.org/10.1002/(SICI)1099-1085(19970630)11:8<873::AID-HYP510>3.0.CO;2-6, 1997.

Rowland, J. C., Travis, B. J., and Wilson, C. J.: The role of advective heat transport in talik development beneath lakes and ponds in discontinuous permafrost, Geophysical Research Letters, 38, https://doi.org/10.1029/2011GL048497, 2011.

Rueda, F. J. and MacIntyre, S.: Modelling the fate and transport of negatively buoyant storm-river water in small multi-basin lakes, Environmental Modelling \& Software, 25, 146-157, https://doi.org/10.1016/j.envsoft.2009.07.002, 2010.

480 Rutan, D. A., Kato, S., Doelling, D. R., Rose, F. G., Nguyen, L. T., Caldwell, T. E., and Loeb, N. G.: CERES Synoptic Product: Methodology and Validation of Surface Radiant Flux, Journal of Atmospheric and Oceanic Technology, 32, 1121-1143, https://doi.org/10.1175/JTECH-D-14-00165.1, 2015.

Smith, A., Lott, N., and Vose, R.: The Integrated Surface Database: Recent Developments and Partnerships, Bulletin of the American Meteorological Society, 92, 704-708, 2011.

485 Spanoudaki, K., Stamou, A. I., and Nanou-Giannarou, A.: Development and verification of a 3-D integrated surface watergroundwater model, Journal of Hydrology, 375, 410-427, https://doi.org/10.1016/j.jhydrol.2009.06.041, 2009.

Stepanenko, V. and Lykossov, V.: Numerical modeling of the heat and moisture transport in a lake-soil system, Russ. Meteorol. Hydrol, 69-75, 2005.

Stepanenko, V., Mammarella, I., Ojala, A., Miettinen, H., Lykosov, V., and Vesala, T.: LAKE 2.0: a model for temperature,

490 methane, carbon dioxide and oxygen dynamics in lakes, Geoscientific Model Development, 9, 1977-2006, https://doi.org/10.5194/gmd-9-1977-2016, 2016.

Stepanenko, V. M., Goyette, S., Martynov, A., Perroud, M., Fang, X., and Mironov, D.: First steps of a Lake Model Intercomparison Project: LakeMIP, Boreal environ. res, 15, 12, 2010.

Stepanenko, V. M., Machul'skaya, E. E., Glagolev, M. V., and Lykossov, V. N.: Numerical modeling of methane emissions

495 from lakes in the permafrost zone, Izv. Atmos. Ocean. Phys., 47, 252-264, https://doi.org/10.1134/S0001433811020113, 2011.

Stepanenko, V. M., Martynov, A., Jöhnk, K. D., Subin, Z. M., Perroud, M., Fang, X., Beyrich, F., Mironov, D., and Goyette, S.: A one-dimensional model intercomparison study of thermal regime of a shallow, turbid midlatitude lake, Geoscientific Model Development, 6, 1337-1352, https://doi.org/10.5194/gmd-6-1337-2013, 2013.

Stepanenko, V. M., Repina, I. A., Ganbat, G., and Davaa, G.: Numerical Simulation of Ice Cover of Saline Lakes, Izv. Atmos.

500 Ocean. Phys., 55, 129-138, https://doi.org/10.1134/S0001433819010092, 2019.

Stepanenko, V. M., Valerio, G., and Pilotti, M.: Horizontal Pressure Gradient Parameterization for One-Dimensional Lake Models, Journal of Advances in Modeling Earth Systems, 12, https://doi.org/10.1029/2019MS001906, 2020.

Sturm, M. and Liston, G. E.: The snow cover on lakes of the Arctic Coastal Plain of Alaska, U.S.A., 49, 370-380, https://doi.org/10.3189/172756503781830539, 2003. 
505 Tan, Z., Zhuang, Q., and Anthony, K. W.: Modeling methane emissions from arctic lakes: Model development and site-level study, Journal of Advances in Modeling Earth Systems, 7, 459-483, https://doi.org/10.1002/2014MS000344, 2015.

Tan, Z., Zhuang, Q., Shurpali, N. J., Marushchak, M. E., Biasi, C., Eugster, W., and Anthony, K. W.: Modeling CO2 emissions from Arctic lakes: Model development and site-level study, Journal of Advances in Modeling Earth Systems, 9, 2190-2213, https://doi.org/10.1002/2017MS001028, 2017.

510 Urban, F.: Data Release associated with Data Series - DOI/GTN-P Climate and Active-Layer Data Acquired in the National Petroleum Reserve-Alaska and the Arctic National Wildlife Refuge, 1998-2019 (ver. 3.0, March 2021), https://doi.org/10.5066/F7VX0FGB, 2017.

Walker, D. A., Raynolds, M. K., Daniëls, F. J. A., Einarsson, E., Elvebakk, A., Gould, W. A., Katenin, A. E., Kholod, S. S., Markon, C. J., Melnikov, E. S., Moskalenko, N. G., Talbot, S. S., and Yurtsev, B. A.: The Circumpolar Arctic vegetation map,

515 Journal of Vegetation Science, 16, 267-282, https://doi.org/10.1111/j.1654-1103.2005.tb02365.x, 2005.

Wielicki, B. A., Barkstrom, B. R., Baum, B. A., Charlock, T. P., Green, R. N., Kratz, D. P., Lee, R. B., Minnis, P., Smith, G. L., Wong, T., Young, D. F., Cess, R. D., Coakley, J. A., Crommelynck, D. A. H., Donner, L., Kandel, R., King, M. D., Miller, A. J., Ramanathan, V., Randall, D. A., Stowe, L. L., and Welch, R. M.: Clouds and the Earth's Radiant Energy System (CERES): algorithm overview, IEEE Transactions on Geoscience and Remote Sensing, 36, 1127-1141, https://doi.org/10.1109/36.701020,

5201998.

Wik, M., Varner, R. K., Anthony, K. W., MacIntyre, S., and Bastviken, D.: Climate-sensitive northern lakes and ponds are critical components of methane release, Nature Geosci, 9, 99-105, https://doi.org/10.1038/ngeo2578, 2016.

Williamson, C. E., Saros, J. E., Vincent, W. F., and Smol, J. P.: Lakes and reservoirs as sentinels, integrators, and regulators of climate change, 54, 2273-2282, https://doi.org/10.4319/10.2009.54.6_part_2.2273, 2009.

525 Zhang, T. and Jeffries, M. O.: Modeling interdecadal variations of lake-ice thickness and sensitivity to climatic change in northernmost Alaska, 31, 339-347, https://doi.org/10.3189/172756400781819905, 2000. 